DOI: http://dx.doi.org/10.33846/hn40701

http://heanoti.com/index.php/hn

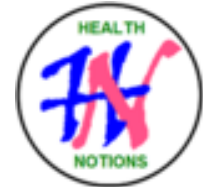

RESEARCH ARTICLE

URL of this article: http://heanoti.com/index.php/hn/article/view/hn40701

\title{
Effectiveness of Asthma Gymnastic on Levels of Tumor Necrosis Factor Alpha (TNF-a) in Asthma Patients
}

\author{
Andi Lis Arming Gandini ${ }^{1(\mathrm{CA})}$, Joko Sapto Pramono ${ }^{2}$, Umi Kalsum ${ }^{3}$, Supriadi ${ }^{4}$, Azhari $^{5}$ \\ ${ }^{1(\mathrm{CA})}$ Department of Nursing, Poltekkes Kemenkes Kalimantan Timur, Indonesia; andilis20@yahoo.com \\ (Corresponding Author) \\ ${ }^{2}$ Department of Nursing, Poltekkes Kemenkes Kalimantan Timur, Indonesia; jokosp2005@yahoo.com \\ ${ }^{3}$ Department of Nursing, Poltekkes Kemenkes Kalimantan Timur, Indonesia; supri.poltekkeskaltim@gmail.com \\ ${ }^{4}$ Department of Nursing, Poltekkes Kemenkes Kalimantan Timur, Indonesia; umi2508@gmail.com \\ ${ }^{5}$ Department of Medical Laboratory Technology, Poltekkes Kemenkes Kalimantan Timur, Indonesia; \\ azharibulkis2@gmail.com
}

\begin{abstract}
Asthma is a chronic inflammation of the airways that involves many cells and their elements. Nonpharmacological treatment of Asthma, one of them is Asthma Gymnastics. The purpose of this study was to determine the effect of asthma exercises on levels of Tumor Necrosis Factor Alpha (TNF- $\alpha$ ) in asthma patients. This study used a quasi-experiment method of pre and post-test with control. The sample size of the intervention group was 8 people and the control group was 7 people. The results of hypothesis testing with the Wilcoxon Test found that there was an influence of asthma gymnastic intervention on the levels of Tumor Necrosis Factor Alpha (TNF- $\alpha$ ) with a p-value of 0.046 . The result of this study showed the effect of asthma exercises on levels of Tumor Necrosis Factor Alpha (TNF- $\alpha$ ) in asthma patients. For further research, it is expected to research by increasing the number of treatments in the intervention group and controlling the drugs taken so that it is more optimal in its effect on respondents.
\end{abstract}

Keywords: asthma; Tumor Necrosis Factor alpha (TNF- $\alpha$ ); asthma gymnastics

\section{INTRODUCTION}

Asthma is a serious global health problem affecting all age groups. Its prevalence is increasing in many countries. The World Health Organization estimates around 235 million people are living with asthma. Over $80 \%$ of asthma related deaths occur in low-and-lower-middle income countriesz ${ }^{(1)}$. Asthma is a heteregoneus disease, usually with history of respiratory symptoms such as wheeze, shortness of breath, chest tightness and cough that very over time and in intensity, together with variable expiratory air flow limitation. Many clinical phenotypes of asthma have been identified, some of the most common include: Allergic Asthma, Non-allergic asthma, adult onset (late-onset) asthma, asthma with persistent airflow limitation and asthma with obesity ${ }^{(2)}$.

Pathophysiology of allergic asthma is traditionally explained by mast cell- and/or Th2 cell-mediated airway inflammation, which is a manifestation of the acquired immune response. TNF- $\alpha$ is produced mainly in macrophages and mast cells, and thymic stromal lymphoprotein, IL-33 and IL-25 are mainly from epithelial cells and various leukocytes. Those molecules are considered to play roles in the innate immune response ${ }^{(3)}$. The role of TNF- $\alpha$ on asthma which is in the increase in channel hyperactivity exhalation, increases responsive excessive smooth muscle breathing, activating myofibroblas and fibroblasts and increase sensitization by increasing release histamine ${ }^{(4)}$.

In up to $90 \%$ of patients with asthma, exercise is a trigger of asthma symptoms. Extensive literature exists supporting the safety and benefits of exercise conditioning on cardiopulmonary fitness, asthma symptoms, 
and asthma-related quality of life ${ }^{(5)}$. Both the American College of Sports Medicine (ACSM) and American Thoracic Society (ATS) recommend regular exercise for patients with asthma. Currently, the ACSM recommends engaging in aerobic exercise at least 2-3 days per week, yet $<50 \%$ of patients meet this recommendation ${ }^{(6)}$.

Asthma Gymnastics is one of the aerobic exercises designed by the Asthma Indonesia Foundation. The benefits of asthma gymnastics are that can practice correct breathing, flexing and strengthening breathing muscles $^{(7)}$. Prevalence of asthma form doctor diagnosis in Indonesia data is 2,4\%. East Borneo occupiesed the second position after Yogyakarta from the National prevalence ${ }^{(8)}$. According from the Samarinda City Health Office in 2016, the first rank asthma was in the Lempake Public Health which was around 13\%, the second was occupied by the Baqa Public Health which was around $11 \%$ and the third was in the Karang Asam Public Health which wa around $9 \%$.

Asthma is incurable, but manageable. Treatment and vigilance and regular medical checks are crucial. Patients can live rewarding, fulfilling lives with the right treatment ${ }^{(1)}$. From several research results, one of which was conducted regular exercise improves asthma controls in adults. The regular exercise was a paralellel 24-week, and 6-month follow up surveys ${ }^{(9)}$. Another research conducted Sudrajat and Nisa (2016) results of asthma exercises regularly will increase the oxygen volume maximally. Asthma exercises has proven can improve lung function such asincrease the value of PEF, FEV1, and $\mathrm{FVC}^{(10)}$. There has not a study of how Asthma Gymnastic can effectived on Tumor Necrosis Factor Alpha (TNF- $\alpha$ ) of asthma patients, so researchers are interested in conducting this research.

\section{METHODS}

This research was used quasy experimental with control group design. The population in this study were students of the Polytechnic of Health of East Kalimantan who had an Asthma history. The sample in this study was 15 respondents divided into 2 (two) groups. First group was 8 repondents whom given the combination of regular drugs and asthma gymnastic and second group was 7 respondents just taken the regular drugs as a control group.

TNF- $\alpha$ examination was carried out in the Samarinda City Regional Health Laboratory, by using respondents' venous blood samples. Data were analyzed using the Wilcoxon Rank test to determine whether there were differences between TNF- $\alpha$ pre-test and post-test scores. This study has been approved by the Ethics Commission on Health Research Ethics at the Poltekkes Kemenkes Kalimantan Timur with an ethics approval letter number LB.02.01/7.1/6626/2018.

\section{RESULTS}

\section{Characteristics of Respondents}

The results of data analysis can be seen in table 1. Characteristic of respondents by gender, it was known that in both groups (intervention and control) the majority were female with a percentage in intervention group of $87.5 \%$ and control group of $100 \%$. Characteristics of respondents based on age obtained in large intervention and control groups were between 20-25 years which is $100 \%$. Characteristics of respondents based on their level of education found that in intervention group the majority were SMA at $87.5 \%$ and control group at $71.4 \%$.

Characteristics of respondents based on body weight according to BMI (Body Mass Index) found that in intervention group most of them had normal weight of 5 people $(62.5 \%)$ and fat weight of 1 person $(12.5 \%)$. In control group, the majority also had normal weight of 4 people $(57.1 \%)$ and a fat weight of 2 people $(28.6 \%)$. Characteristics of respondents based on smoking habits found that in intervention and control groups most do not smoke with a percentage of $100 \%$. Characteristics of respondents based on the hypothesis in intervention group of $62.5 \%$ and allergic to air pollution by $87.5 \%$. In the control group also most of them have a weather hypothesis of $57.1 \%$ and an association with air pollution of $85.7 \%$. 
Table 1. Characteristics of respondents

\begin{tabular}{|c|c|c|c|c|}
\hline \multirow{2}{*}{ Variable } & \multicolumn{2}{|c|}{ Intervention group } & \multicolumn{2}{|c|}{ Control group } \\
\hline & Frequency & Percentage & Frequency & Percentage \\
\hline \multicolumn{5}{|l|}{ Gender } \\
\hline 1. Male & 1 & 12.5 & 0 & 0.0 \\
\hline 2. Female & 7 & 87.5 & 7 & 100 \\
\hline \multicolumn{5}{|l|}{ Age } \\
\hline $20-25$ years & 8 & 100 & 7 & 100 \\
\hline \multicolumn{5}{|l|}{ Education } \\
\hline 1. Senior High School & 7 & 87.5 & 5 & 71.4 \\
\hline 2. 3-year diploma & 0 & 0.0 & 1 & 14.3 \\
\hline 3. Undergraduated & 1 & 12.5 & 1 & 14.3 \\
\hline \multicolumn{5}{|l|}{ Weight (IMT) } \\
\hline 1. Thin & 1 & 12.5 & 1 & 14.3 \\
\hline 2. Normal & 5 & 62.5 & 4 & 57.1 \\
\hline 3. Fat & 1 & 12.5 & 2 & 28.6 \\
\hline 4. Obesitas & 1 & 12.5 & 0 & 0.0 \\
\hline \multicolumn{5}{|l|}{ Smoking habit } \\
\hline 1. Smoking & 0 & 0.0 & 0 & 0.0 \\
\hline 2. Not smoking & 8 & 100 & 7 & 100 \\
\hline \multicolumn{5}{|l|}{ Allergy } \\
\hline \multicolumn{5}{|l|}{ 1. Food } \\
\hline Yes & 3 & 37.5 & 3 & 42.9 \\
\hline No & 5 & 62.5 & 4 & 57.1 \\
\hline \multicolumn{5}{|l|}{ 2. Weather } \\
\hline Yes & 7 & 62.5 & 4 & 57.1 \\
\hline No & 1 & 37.5 & 3 & 42.9 \\
\hline \multicolumn{5}{|l|}{ 3. Air pollution } \\
\hline Yes & 7 & 62.5 & 6 & 85.7 \\
\hline No & 1 & 37.5 & 1 & 14.3 \\
\hline Total & 8 & 100 & 7 & 100 \\
\hline
\end{tabular}

\section{Distribution of Respondents Based on TNF- $\alpha$ Levels of Intervention Groups}

Table 2. Distribution of respondents based on TNF- $\alpha$ Levels of Intervention Groups

\begin{tabular}{lccc}
\hline Level $T N F-\alpha$ & Mean & SD & $\mathrm{n}$ \\
\hline Before intervention & 2064.25 & 1099.99 & 8 \\
After intervention & 1047.15 & 691.22 & 8 \\
\hline
\end{tabular}




\section{Distribution of Respondents Based on TNF- $\alpha$ Levels of the Control Group}

Table 3. Distribution of Respondents Based on TNF- $\alpha$ Levels of the Control Group

\begin{tabular}{lccc}
\hline Level $T N F-\alpha$ & Mean & SD & $\mathrm{n}$ \\
\hline Before intervention & 1892.23 & 928.48 & 7 \\
After intervention & 912.75 & 603.16 & 7 \\
\hline
\end{tabular}

The Results of the Wilcoxon Test Analysis TNF- $\alpha$ Levels Before the Intervention and After the Asthma Gymnastic Intervention in the Intervention Group

Table 4. The results of the Wilcoxon Test analysis TNF- $\alpha$ levels before the intervention and after the asthma gymnastic intervention in the intervention group

\begin{tabular}{ccccc}
\hline Level $T N F-\alpha$ & Med. & Max. & Min. & p-value \\
\hline Before intervention & 1736,91 & 3850 & 691 & \multirow{2}{*}{0,017} \\
After intervention & 722,76 & 2476 & 513 & \\
\hline
\end{tabular}

Average different tests before and after the asthma gymnastic intervention in the intervention group using the Wilcoxon test obtained p-value TNF- $\alpha$ level $=0.017$, this shows $\mathrm{p}$-value $<0.05$ which means there was a statistically significant difference in the TNF- $\alpha$ level in asthma gymnastic group intervention.

\section{The results of the Wilcoxon Test analysis of TNF- $\alpha$ levels were only taking drugs in the Control group}

Table 5. The results of the Wilcoxon Test analysis of TNF- $\alpha$ levels were only taking drugs in the control group

\begin{tabular}{lcccl}
\hline Level $T N F-\alpha$ & Med. & Max. & Min. & p-value \\
\hline Before intervention & 1874,62 & 3392 & 705 & \multirow{2}{*}{ (1818 } \\
After intervention & 814,06 & 2226 & 487 & \\
\hline
\end{tabular}

Average different tests before and after in the control group using the Wilcoxon test obtained p-value TNF- $\alpha$ level $=0.018$, this shows $p$-value $<0.05$ which means there was a significant difference in the TNF- $\alpha$ level in control group.

\section{DISCUSSION}

The study results showed that there were differences in TNF- $\alpha$ before and after administration of gymnastic asthma. Asthma gymnastics is a type of sports therapy carried out in groups (group exercises) that involve body movement activities or is an activity that helps the process of respiratory rehabilitation in asthmatics $^{(11)}$. Asthma exercises have many benefits both physical and psychological or social benefits. Physical benefits include optimizing the breathing muscles and the patient can breathe properly during an attack. Psychological or social benefits include increased comfort and confidence and reducing the need for medicines $^{(12)}$.

Asthma gymnastics improvements muscle expiration ability, reduced airway obstruction and inflammation. Reduced obstruction causes decreased pulmonary hyperinflation and movement the diaphragm becomes better so that the volume inspiration becomes greater. Physiology repair Lungs occur due to 
movements of gymnastics improve the ability of muscles respiration. Increased muscle ability caused by changes in the form hypertrophy, increasing number of mitochondria, oxidative enzymes and myoglobin. Lung physiology increased apart from movement as well caused by previous sufferers not never gymnastics ${ }^{(13)}$.

Research conducted by Huldani (2016) states that aerobic exercise will stimulate muscle damage caused by local inflammation so that the muscles degenerate and regenerate around the connective tissue. Neutrophils will be transferred to circulation after physical activity, and immediately infiltrate the damaged tissue. Neutrophils will be taken up by chemoattractants such as complement 5a (C5a) and interleukin (IL) -8 from cell damage due to physical activity ${ }^{(14)}$.

Neutrophils are in the muscles one day after physical exercise, and after neutrophil infiltration, macrophages will replace and settle in the muscles 1-14 days after physical activity. Although there is evidence of severe muscle damage after eccentric exercise, this muscle damage is not accompanied by large changes in plasma cytokine concentrations. Small changes in systemic cytokine concentrations found in this study might reflect faster circulatory clearance, or the absence of significant metabolic or oxidative requirements during certain training patterns. Moderate exercise training may have a role in stimulating the immune system in certain diseases (for example, HIV-infection), immune dysfunction (for example, chronic fatigue syndrome) or $\operatorname{aging}^{(15)}$.

\section{CONCLUSION}

Based on the study results, there are differences in Tumor Necrosis Factor-alpha (TNF- $\alpha$ ) levels where there is a decrease in TNF Alpha after being given asthma gymnastics. Asthma Gymnastics is effective in reducing TNF- $\alpha$, for this reason it is recommended to the Samarinda City Health Office government to make this activity as a permanent program in all Public Health Center in Samarinda. Future studies are expected to examine by increasing the number of treatments in the intervention group and controlling the drugs taken so that the effect is more optimal for respondents.

\section{REFERENCES}

1. World Health Organization. Asthma [Internet]. 2019. Available from: https://www.who.int/news-room/qa-detail/asthma

2. Global Initiative for Asthma. Global Strategy for Asthma Management and Prevention Updated 2019. Global. 2019;49(5).

3. Nabe T. Tumor Necrosis Factor Alpha-Mediated Asthma? Int Arch Allergy Immunol. 2013;160(2):111-3.

4. Apriansyah MA, Putranto R, Salim EM, Shatri H, Ilmu D, Dalam P, et al. The Correlation of Depression Level with Tumor Necrosis Alpha ( TNF- $\alpha$ ) Concentration in Uncontrolled Bronchial Asthma Patients. 2016;3(2):74-80.

5. Carson K, Chandratilleke M, Picot J, Brin M, Esterman A, Smith B. Physical Training for Asthma (Review). Cochrane Collab. 2013;(9).

6. Corbridge SJ, Nyenhuis SM. Promoting Physical Activity and Exercise in Patients With Asthma and Chronic Obstructive Pulmonary Disease. J Nurse Pract [Internet]. 2017;13(1):41-6. Available from: http://dx.doi.org/10.1016/j.nurpra.2016.08.022

7. Keputusan Menteri Kesehatan RI. Pedoman Pengendalian Penyakit Asma. 2008. p. 4-16.

8. Badan Penelitian dan Pengembangan Kesehatan Kementerian Kesehatan RI. Hasil Utama RISKESDAS 2018 [Internet]. Vol. 44. 2018.

9. Jaakkola JJK, Aalto SAM, Hernberg S, Kiihamäki SP, Jaakkola MS. Regular Exercise Improves Asthma Control in Adults: A Randomized Controlled Trial. Sci Rep. 2019;9(1):1-11.

10. Sudrajat NU, Nisa K. Efektifitas Senam Asma untuk Meningkatkan Fungsi Paru Penderita Asma. Major J. 2016;5(4):112-6.

11. Del Giacco SR, Firinu D, Bjermer L, Carlsen K-H. Exercise and Asthma: An Overview. Eur Clin Respir J. 2015;2(1):27984.

12. Francisco C de O, Bhatawadekar SA, Babineau J, Darlene Reid W, Yadollahi A. Effects of Physical Exercise Training on Nocturnal Symptoms in Asthma: Systematic Review. PLoS One. 2018;13(10):1-18.

13. Prajapati R, Shrestha B, Dhungel S, Devkota KC, Pramanik T, Roychowdhury P. Spirometric Evaluation of Pulmonary Function Tests in Clinically Diagnosed Patients of Bronchial Asthma. Nepal Med Coll J. 2010;12(1):45-7.

14. Huldani H. Pengaruh Latihan Aerobik Ringan dan Sedang terhadap Kadar Interleukin 8 dan Jumlah Netrofil pada Remaja. Berk Kedokt. 2016;12(1):61. 
15. Neubauer O, Sabapathy S, Lazarus R, Jowett JBM, Desbrow B, Peake JM, et al. Transcriptome analysis of neutrophils after endurance exercise reveals novel signaling mechanisms in the immune response to physiological stress. J Appl Physiol. 2013;114(12):1677-88. 